\title{
Review \\ The Next-Generation Immune Checkpoint LAG-3 and Its Therapeutic Potential in Oncology: Third Time's a Charm
}

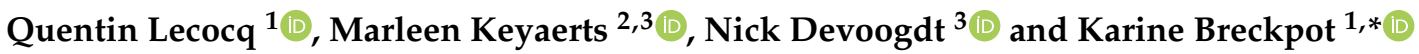 \\ 1 Laboratory for Molecular and Cellular Therapy (LMCT), Vrije Universiteit Brussel, Laarbeeklaan 103, \\ B-1090 Brussels, Belgium; quentin.lecocq@vub.be \\ 2 Nuclear Medicine Department, UZ Brussel, Laarbeeklaan 101, B-1090 Brussels, Belgium; \\ Marleen.Keyaerts@vub.be \\ 3 In Vivo Cellular and Molecular Imaging Laboratory (ICMI), Vrije Universiteit Brussel, Laarbeeklaan 103, \\ B-1090 Brussels, Belgium; ndevoogd@vub.be \\ * Correspondence: Karine.Breckpot@vub.be
}

Citation: Lecocq, Q.; Keyaerts, M.; Devoogdt, N.; Breckpot, K. The NextGeneration Immune Checkpoint LAG3 and Its Therapeutic Potential in Oncology: Third Time's a Charm. Int. J. Mol. Sci. 2021, 22, 75. https:// dx.doi.org/10.3390/ijms22010075

Received: 9 November 2020 Accepted: 18 December 2020 Published: 23 December 2020

Publisher's Note: MDPI stays neutral with regard to jurisdictional claims in published maps and institutional affiliations.

Copyright: $\odot 2020$ by the authors. Licensee MDPI, Basel, Switzerland. This article is an open access article distributed under the terms and conditions of the Creative Commons Attribution (CC BY) license (https: / / creativecommons.org/ licenses/by/4.0/).

\begin{abstract}
The blockade of immune checkpoints (ICPs), such as cytotoxic T lymphocyte associated protein-4 (CTLA-4) and programmed death-1 (PD-1) and its ligand (PD-L1), has propelled the field of immuno-oncology into its current era. Drugs targeting these ICPs have improved clinical outcome in a number of patients with solid and hematological cancers. Nonetheless, some patients have no benefit from these ICP-blocking therapies. This observation has instigated research into alternative pathways that are responsible for the escape of cancer cells from anti-cancer immune responses. From this research, a number of molecules have emerged as promising therapeutic targets, including lymphocyte activating gene-3 (LAG-3), a next-generation ICP. We will review the current knowledge on the biological activity of LAG-3 and linked herewith its expression on activated immune cells. Moreover, we will discuss the prognostic value of LAG-3 and how LAG-3 expression in tumors can be monitored, which is an aspect that is of utmost importance, as the blockade of LAG-3 is actively pursued in clinical trials.
\end{abstract}

Keywords: LAG-3; immune checkpoint; immunotherapy; diagnosis; cancer; oncology

\section{Introduction}

Immune cells are controlled by a plethora of molecules that act as "security brakes" at multiple stages of the immune response. These regulations are important to prevent the destruction of tissues caused by inappropriate and/or disproportionate responses to invading pathogens. Cancer cells exploit such inhibitory immune checkpoints (ICPs) to escape destructive tumor-specific immune responses, which is unfavorable for the patients' outcome.

In 2018, cancer caused 9.6 million deaths and was diagnosed in 18.1 million patients worldwide [1]. Cancer treatments focusing on reinvigorating exhausted tumor-specific immune cells significantly improved the survival of patients. In particular, the anti-tumor effects observed after monoclonal antibody (mAb)-mediated the blockade of the ICPs; cytotoxic T lymphocyte associated protein-4 (CTLA-4, CD152), programmed death-1 (PD-1, CD279) and its ligand PD-L1 (CD274, B7-H1), revolutionized the field of immuno-oncology. Therapeutic success was achieved in a fraction of patients and provided clinical evidence that corroborated the preclinical finding that ICPs exert inhibitory effects on immune cells that try to eradicate cancer cells. However, the response frequencies to these widely used ICP-blocking mAbs are suboptimal as a consequence of, amongst others, tumor resistance, an absence of tumor-infiltrating lymphocytes (TILs), and the presence of inhibitory myeloid cells [2]. Moreover, the occurrence of immune-related adverse events (irAEs) has been a reason to discontinue the use of ICP-blocking mAbs. Taken together, researchers are 
continuously untangling the biology of inhibitory receptors to increase response rates and to prevent irAEs.

The list of inhibitory ICPs that negatively regulate anti-tumor immune responses is growing. Among these next-generation ICPs, lymphocyte activating gene-3 (LAG-3, CD233) has emerged as an eminent target in the development of cancer treatment and holds substantial prognostic value. With as many as 15 different compounds targeting LAG-3 under (pre)clinical evaluation, it is the most widely studied ICP next to CTLA-4 and PD-1/PD-L1. LAG-3, also known as CD223, is expressed on numerous immune cell types, where its exact mechanism of action is yet to be fully discovered. However, it is certain that LAG-3 shows a remarkable synergy with PD-1 in promoting immune escape of cancer cells [3-6]. Notably, the simultaneous blockade of LAG-3 and PD-1 has shown striking clinical results in melanoma patients that were not responding well to initial PD-1 or PD-L1 monotherapy [7,8].

The growing list of inhibitory ICPs brings forth the challenge of defining which patients are likely to benefit from ICP therapy and which inhibitory ICP(s) prevail(s) in the patients' tumors and therefore should be targeted. Presently, patients are selected for treatment with ICP-blocking mAbs, depending on the level of inhibitory ICP expression in the tumor microenvironment (TME), which is determined using immunohistochemistry (IHC). The static picture created by the IHC of a tumor biopsy does not take in account the heterogeneously distributed expression of ICPs. The latter can explain the fact that "nonexpressors" do respond to ICP-blocking therapies [9]. Contrarily, some patients with IHC samples that show a clear expression of ICPs in the TME are observed not to react to ICPblocking mAbs $[10,11]$. This can be due to amongst others, the compensatory expression of other ICPs $[9,12,13]$. Recent studies explored the field of molecular imaging as a more suited alternative for the non-invasive detection of ICPs in cancer patients. Molecular imaging allows the whole body visualization of prognostic or predictive markers. It can be performed non-invasively and repetitively, which allows quantifying and tracking of the dynamic evolution of expression patterns.

The aim of this review is to provide an overview of the biology of LAG-3 in the context of cancer as well as to provide an overview on the strategies used to detect and block LAG-3.

\section{The Receptor LAG-3 and Its Interaction Partners}

LAG-3, also called CD223, was identified in 1990 as a receptor that was expressed on a natural killer (NK) cell line cultured with interleukin (IL)-2 [14]. A close relationship with the cell surface protein CD4 was shown in terms of location and organization of its coding region as well as in terms of amino acid sequence and protein structure. The LAG-3 gene is located on the distal portion of the short arm of human chromosome 12 (12p13.31), which is adjacent to the coding region for CD4, and contains eight exons [15]. The conservation of LAG-3 among species is shown by its $70 \%$ and $78 \%$ homology with murine [14] and pig [16] LAG-3, respectively. The protein LAG-3 is 503 amino acids large, weighs $70 \mathrm{kDa}$, and is a type I transmembrane protein that contains four extracellular Immunoglobulin (Ig)-like domains termed domain 1 to 4 . Approximately $20 \%$ of its amino acid sequence is identical to the CD4 protein, which is mostly pronounced in the extracellular region [14,17]. In contrast, the intracellular region of CD4 and LAG-3 lack homology, suggesting different functions. Due to the extracellular similarity, CD4 and LAG-3 share the same ligand, i.e., major histocompatibility complex class II (MHC-II) proteins. In LAG-3, a 30 amino acid long "extra loop" in domain 1 has been reported to engage MHC-II [18,19]. Notably, LAG-3 does not universally recognize MHC-II/peptide (pMHC-II) complexes on the surface of antigen-presenting cells (APCs). LAG-3 has been shown to selectively bind pMHC-II complexes that are considered stable after H2-DM has replaced the class-II-associated invariant chain peptide or unstable peptides by peptides with high affinity for the peptidebinding groove of MHC-II. LAG-3 is able to bind these stable pMHC-II complexes with a stronger affinity than CD4 [15,18-21]. Several other ligands interact with LAG-3, including 
Galectin-3 (Gal-3), liver sinusoidal endothelial cell lectin (LSECtin, CLEC4G) and fibrinogen like protein 1 (FGL-1) (Figure 1).

A.

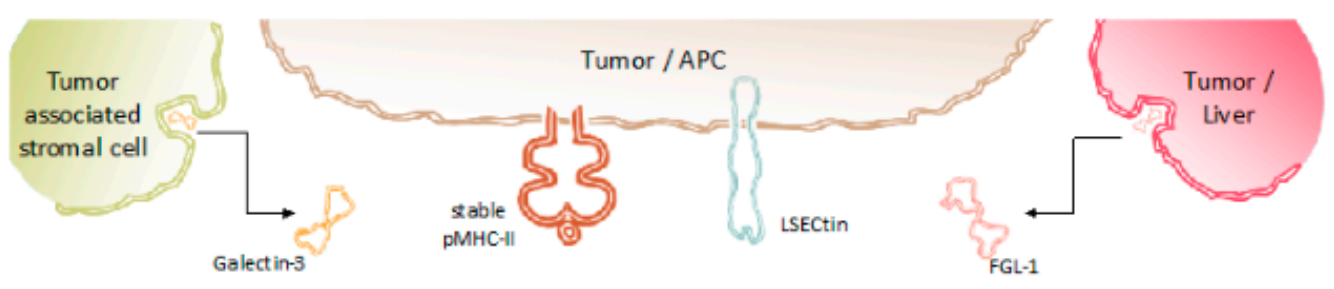

B.
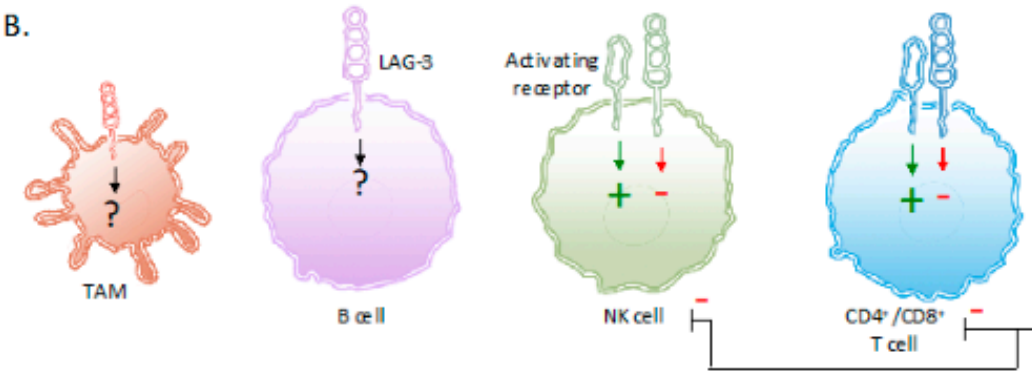

C.
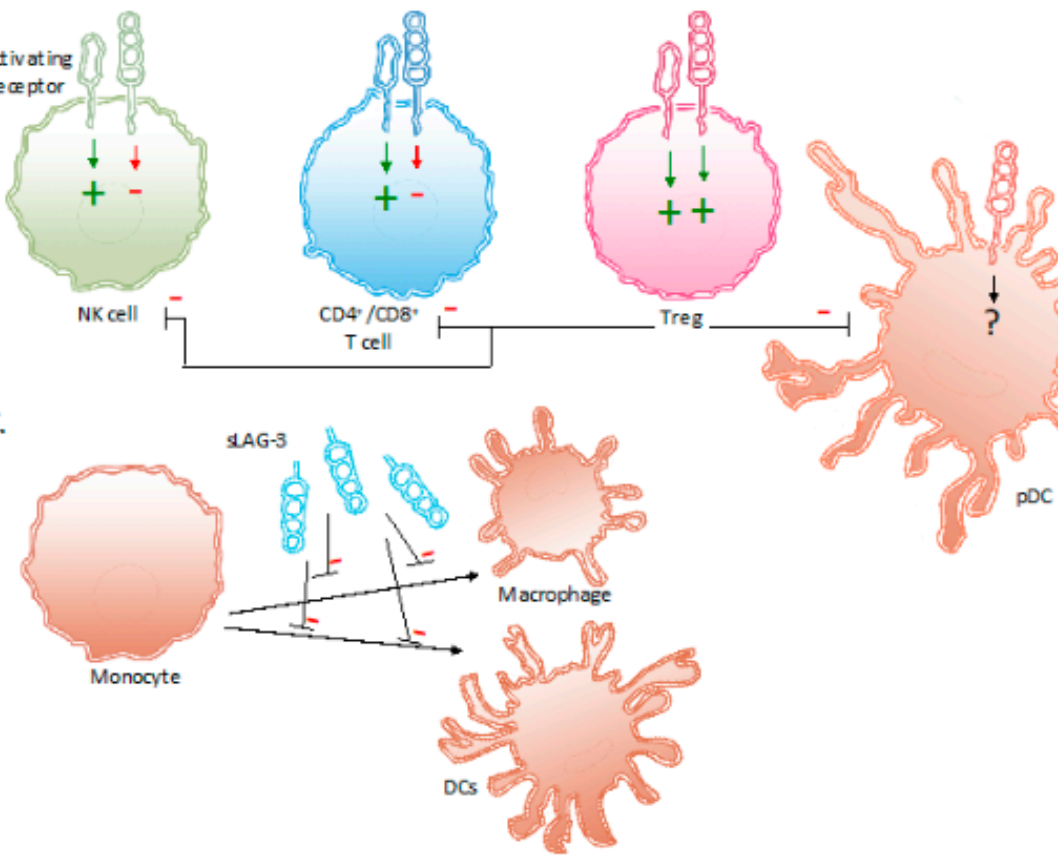

$\mathrm{pDC}$

Figure 1. Expression of LAG-3 and its ligands in the TME. (A) Binding partners reported to associate with LAG-3 are stable pMHC-II complexes, Gal-3, LSECtin and FGL-1. These LAG-3 ligands are expressed on APCs, tumor cells and tumor-associated stromal cells. (B) Expression of LAG-3 on different immune cells and its influence on their effector functions. (C) sLAG-3 inhibiting the differentiation of monocytes towards macrophages or DCs. Abbreviations: APC, antigen-presenting cell; FGL-1, fibrinogen-like protein 1; Gal-3, Galectin-3; LSECtin, liver sinusoidal endothelial cell lectin; NK, natural killer; pDC, plasmacytoid dendritic cell; pMHC-II, peptide major histocompatibility complex class II; sLAG-3, soluble LAG-3; TAM, tumor-associated macrophage; TME, tumor microenvironment; Treg, regulatory T cell.

LSECtin is mainly expressed in the liver and has been found on the surface of tumor cells, such as human melanoma cells, as an engendered mechanism of immune escape [22,23]. Gal-3 is a soluble molecule secreted by a variety of tumor cells and tumorassociated stromal cells. It interacts with LAG-3 and was observed to reduce the frequency of $\mathrm{CD}^{+} \mathrm{T}$ cells producing interferon gamma (IFN- $\gamma$ ) in the TME [24,25]. The fourth ligand of LAG-3, FGL-1, has been identified more recently. FGL-1 is produced and secreted by tumor cells and hepatocytes. Preclinical work showed that FGL-1 reduced the production of IL-2 by a T-cell line, when interacting with LAG-3 on the T-cell surface [26].

\section{Expression of LAG-3 and Its Regulation in Tumor-Associated Immune Cells}

As illustrated in Figure 1, the expression of LAG-3 in the TME has been observed on TILs [27], in particular $\mathrm{CD}^{+}$and $\mathrm{CD}^{+} \mathrm{T}$ cells [14,28], including regulatory $\mathrm{T}$ cells (Tregs) [29]; NKT cells [30]; B cells [31]; NK cells [32] as well as on plasmacytoid dendritic cells (pDCs) $[33,34]$ and tumor-associated macrophages (TAMs) $[35,36]$. 
It has been shown that LAG-3 expression on $\mathrm{CD}^{+}$and $\mathrm{CD} 8^{+} \mathrm{T}$ cells, even NKT cells, is induced upon continued antigen stimulation further stimulated through exposure to IFN- $\gamma$, IL-2, IL-7, and/or IL-12 [20,30,37,38]. Several transcriptional regulators have been implicated in the regulation of LAG-3 expression and T-cell exhaustion, which is the state of most TILs. These are thymocyte selection-associated high mobility group box protein (TOX), nuclear factor of activated T cells (NFAT), and nuclear receptor subfamily 4 , group A (NR4A) [39-44]. LAG-3 expression is further regulated through its trafficking in cells [45]. In addition, proteolytic cleavage by ADAM10 and ADAM17, two metalloproteases, regulates LAG-3 levels on the T-cell surface, allowing T-cell activation in the initiation phase of the immune response [46]. However, sustained antigen stimulation forces LAG-3 expression on the cell surface, leading to the loss of T-cell effector functions and the development of an exhausted state.

Several Treg-populations have been characterized by high and constitutive expression of LAG-3 [47-49]. These include CD4 ${ }^{+}$Foxp $^{+}$Tregs, IL-10 producing $\operatorname{Tr} 1$ cells as well as IL-10 and transforming growth factor beta (TGF- $\beta$ ) 3 producing CD4 ${ }^{+}$Foxp3- Tregs. It has been hypothesized that this constitutive LAG-3 expression is due to continuous TCR signaling by self-antigens, which is recognized by these Treg-populations, implicating the same transcriptional regulators, as described for $\mathrm{CD}^{+}$and $\mathrm{CD}^{+} \mathrm{T}$ cells with an effector function [50]. Moreover, early growth response gene 2 (EGR2) has been described as a critical regulator of LAG-3 expression in CD4 $4^{+}$Foxp3- Tregs [29].

The expression of LAG-3 on B cells has not been elucidated on the molecular level. However, it has been shown to depend on activated $T$ cells [31]. B cells have been shown to express LAG-3 when cultured with anti-CD3 antibody activated T cells, however, not when stimulated with antibodies that bind the B-cell receptor and CD40, mimicking interaction with $\mathrm{CD} 4^{+} \mathrm{T}_{\mathrm{H}}$ cells. Further analysis of the mechanisms leading to LAG-3 acquisition on the B-cell surface has revealed the need for a soluble factor to induce endogenous LAG-3 expression in B cells with IL-6 being a good candidate. It has been further shown using LAG-3 knock-out cells that LAG-3 detected on B cells upon co-culture with activated T cells can further be acquired through the absorption of LAG-3 from activated T cells.

The regulation of LAG-3 expression on cells of the innate immune system, including NK cells, pDCs, and macrophages, has yet to be elucidated. Although some hints to the signals that can induce LAG-3 expression on NK cells and pDCs are available, the molecular mechanisms are not yet described. LAG-3 expression has been induced on NK cells using IL-12 [51-53]. Moreover, a subpopulation of NK cells, more specifically NKG2 $\mathrm{C}^{+} \mathrm{NK}$ cells, have been shown to express LAG-3 in response to interaction with an NKG2C agonist and IL-15 [32]. These cells further showed increased PD-1 expression, suggesting that LAG-3 and PD-1 expression coincide in this NK cell population, similar as in T cells. LAG-3 expression has been shown on a subset of pDCs in healthy individuals as well as on pDCs in melanoma patients with a clear enrichment in LAG-3 ${ }^{+}$pDCs in melanoma-invaded lymph nodes and in cutaneous melanoma metastasis. Moreover, it was shown that stimuli such as IL-3 and CpG DNA could stimulate LAG-3 expression on these cells [34].

\section{Signaling Induced by LAG-3 and Its Net Effect}

Thirty years after its discovery, the exact signaling pathway of LAG-3 remains unknown. Compared to other ICPs such as PD-1 and CTLA-4, LAG-3 does not have immunoreceptor tyrosine-based inhibitory motifs (ITIM) present in its cytoplasmatic tail. It has been shown that the inhibitory effect of LAG-3 is not caused by competitive pMHC-II binding with CD4 [21,28]. Instead, Workman et al. reported an intracellular "KIEELE" sequence in the intracellular part of LAG-3 on $\mathrm{CD}^{+} \mathrm{T}$ cells that is necessary to transduce distinctive yet undetermined inhibitory signals [19]. This finding was recently contradicted in a study reporting that LAG-3 elicits inhibitory mechanisms through an FXXL motif present in the membrane-proximal regions in cooperation with a C-terminal EX repeat [54]. The latter is found to interact with a so-called LAG-3-associated protein (LAP) [55]. The 
inhibitory effect of LAG-3 was lost upon deletion of the EX repeat and when mutations were induced in the FXXL sequence [54]. Although the molecular mechanisms exploited by LAG-3 to install inhibitory signals are slowly being uncovered, there is still much to learn about LAG-3 and how its atypical cytoplasmic motifs interact with cytoplasmic signaling proteins.

The biological activity of LAG-3 is most intriguing. LAG-3 has been shown to transduce inhibitory signals on activated $\mathrm{CD}^{+} \mathrm{T}$ cells even though the activation of CD8 ${ }^{+}$ $\mathrm{T}$ cells is not driven by peptide presentation in MHC-II. Nonetheless, the inhibition of $\mathrm{CD}^{+} \mathrm{T}$-cell activation has been shown to be induced by APCs that express high amounts of pMHC-II in addition to pMHC-I [21]. Moreover, together with the co-expression of PD-1, the anti-tumor immunity of $\mathrm{CD}^{+} \mathrm{T}$ cells could be abolished through the interaction with LAG-3's other ligands i.e., LSECtin, FGL-1, and Gal-3 found in the TME $[23,24,26,56]$. Furthermore, Tregs present in the TME are renowned to weaken cancer-specific immune responses through the downregulation of inflammatory cytokines and the upregulation of suppressor activity. The role of LAG-3 has been shown to be essential in supporting Treg activity [47]. Research in non-small-cell lung cancer (NSCLC) patients show elevated LAG-3 expression on Tregs residing in the tumor compared to Tregs found in peripheral blood and normal tissues $[57,58]$. The surface expression of LAG-3 on Tregs has been shown to increase the secretion of immune suppressive cytokines, such as IL-10 and TGF- $\beta[57,58]$. These cytokines elicit inhibitory effects on the activity of CD8 ${ }^{+} \mathrm{T}$ cells, NK cells, and DCs. Furthermore, Tregs directly inhibit pDCs through LAG-3-pMHC-II interactions. These have been shown to initiate suppressive pathways, which hamper the proliferation and maturation of DCs [59]. Moreover, of all DC subsets, pDCs constitutively express LAG-3, which in turn negatively regulates their activation, intrinsic physiology, and extrinsic interplay with T cells [33]. Consequently, tumor-infiltrating pDCs expressing LAG-3 have been shown to contribute to an anti-inflammatory environment in melanoma patients [34]. The direct role of LAG-3 expressed on activated NK cells is still not fully understood. Although upregulated on human NK cells in response to IL-12, the blockade of LAG-3 on NK cells has shown no specific influence on their functionality [51-53]. However, on NKT cells expressing both NK receptors and T cells receptors, LAG-3 has shown to downregulate their proliferation [30]. As mentioned above, the expression of LAG-3 on B cells has been shown to be T-cell dependent [31]. More recently, Lino et al. identified a plasma B cell subset, selectively expressing LAG-3, with immune suppressing activity through the production of IL-10 [60]. Additionally, digital spatial protein analysis demonstrated the expression of LAG-3 in TAMs [35]. Although its role is still not fully understood, it can be speculated that LAG-3 expression on TAMs contributes to their tumor-promoting function, as suggested by the association of co-expression of CD163 and LAG-3 with poor clinicopathological indexes in melanoma [36] and metastatic ovarian cancer [61]. As mentioned above, LAG-3 can be cleaved from the cell surface by ADAM10 and ADAM17 and form soluble LAG-3 (sLAG-3) [46]. sLAG-3 regulates immune responses in the TME and periphery, for example by inhibiting the differentiation of monocytes to macrophages or DCs (Figure 1) [62-64].

\section{The Prognostic Value of LAG3}

LAG-3 is known to promote tumor escape through an induction of immunosuppression [21,65-67]. Consequently, the presence of LAG-3 on tumor-infiltrating immune cells has been described to be associated with poor prognosis and tumor progression. Individual studies reported this observation for various tumor types, including renal cell carcinoma [68], gastric cancer [69], bladder cancer [70], colorectal cancer [71], chronic lymphocytic leukemia [72], acute myeloid leukemia [73], follicular lymphoma [74], hepatocellular carcinoma [75,76], NSCLC [58], head and neck squamous cell carcinoma [77], esophageal squamous cell carcinoma [78], and diffuse large B cell lymphoma [79]. These studies suggested a contribution of LAG-3 to immune escape by the tumor, similarly to PD-1. 
Paradoxically, some clinical reports indicated a favorable outcome of cancer patients when LAG-3 expression is observed on tumor-infiltrating immune cells. This is the case for breast cancer [80,81], esophageal adenocarcinoma [82], and advanced gastric cancer patients treated with PD-1 blocking mAbs [83]. Here, LAG-3 expression could be considered a marker for T-cell activation. Moreover, Saleh et al. [84] recently performed a metaanalysis on the prognostic value of LAG-3 expression in a variety of tumor types, observing that LAG-3 expression was associated with a better overall survival (OS), particularly in patients with early stage disease [84]. This might be explained by the fact that LAG-3 is expressed on activated immune cells, such as $\mathrm{CD}^{+} \mathrm{T}$ cells, and therefore might reflect infiltration of the tumor and initial tumor control by these immune cells [81,85]. Similarly, the expression of ICP PD-L1 and CTLA-4 have been previously associated with improved tumor outcomes [86-88].

The contradictory observations made about the prognostic value of LAG-3 expression in cancer patients could be associated to the difference in evaluated tumor type. However, more research is required to confirm if a tumor-specific prognostic value of LAG-3 really exists.

\section{Immunohistochemistry and Imaging of the Immune Checkpoint LAG-3}

The expression of LAG-3 is mostly studied using next-generation sequencing or IHC. The latter comprises the need to acquire invasive biopsies and cannot be considered a representative image of the heterogeneous distribution of ICPs within the TME. More importantly, the dynamic expression of ICPs and its role outside the TME can cause misinterpretation when IHC is used as a selection tool to predict therapy outcome. These limitations are summarized elsewhere more extensively [89]. In contrast to IHC, the use of molecular imaging to non-invasively detect molecules throughout the patient's body has proven to be a more effective way to correlate therapy outcome [90,91]. As illustrated in Figure 2, IHC generates a static picture of a selected area of one tumor lesion compared to the possibility of nuclear imaging to generate whole body target distribution profiles. Moreover, nuclear imaging can be performed repetitively, regardless of the tumors' location. For example, $\mathrm{mAbs}$ targeting PD-1 or PD-L1 were radiolabeled with isotopes for positron emission tomography (PET) and intravenously injected in cancer patients. After scanning the patients, molecular imaging was proven to be more accurate in predicting response to ICP therapy compared to the use of IHC [90,91]. Moreover, recent preclinical studies have evaluated the use of nanobodies as targeting moiety for radionuclide imaging, which provided high-contrast images within $2 \mathrm{~h}$ after injection, enabling its straightforward implementation in clinical routine $[9,89,92]$.

In view of LAG-3 detection, we report two recent preclinical studies that evaluated molecular imaging for non-invasive mapping of LAG-3 using a mAb or a nanobody. Kelly et al. described, in a congress report, the use of a Zirconium ${ }^{89}\left({ }^{89} \mathrm{Zr}\right)$ labeled antibody directed against human LAG-3 [93]. Mice, subcutaneously implanted with a mix of human cancer and immune cells, were subjected to PET scans after administration of the radiolabeled antibody. ${ }^{89} \mathrm{Zr}$-DFO-REGN3767 specifically accumulated in the tumor, spleen, and axillary lymph nodes 6 days after administration to the mice. The visualization of radioactivity suggests the presence of LAG-3 expression on cells residing in these tissues. However, due to poor penetration capacity and slow clearance of free tracer, the radiolabeled antibody needed up to 6 days to map LAG-3 with high contrast, and thus, radioisotopes with longer half-lives were required. When translated to a clinical setting, the injected patient will have to wait a substantial amount of time before a scan can be performed. Moreover, during this "incubation" time the patient is exposed to a considerable amount of radioactivity [94]. Therefore, research has focused on using smaller binding moieties with better in vivo penetration capacity to non-invasively detect LAG-3. We reported a nanobody that binds mouse LAG-3 [95]. Nanobodies are derived from the antigen-binding domain of heavy-chain only antibodies found in among other camelids [89]. A feature of nanobodies is that they are around ten times smaller in size than mAbs. As a consequence, 
nanobodies can easily penetrate dense tissues such as tumors [96,97]. Other advantageous traits include high specificity, high affinity, high (thermo)stability, low off-target accumulation, and good solubility [98]. Additionally, nanobodies have been described that are able to transmigrate through the blood-brain barrier [99-101]. Preclinical evaluation in mice showed the feasibility of detecting LAG-3 as soon as one hour after injection with radiolabeled nanobodies [95]. Moreover, due to its small size, unbound radiolabeled nanobodies are quickly filtered from the blood by the kidneys to end up in the urine, avoiding long exposure to the decaying isotope [102]. This would mean that a patient could be scanned quickly after administration and, depending on the target, enrolled for appropriate ICP therapy.

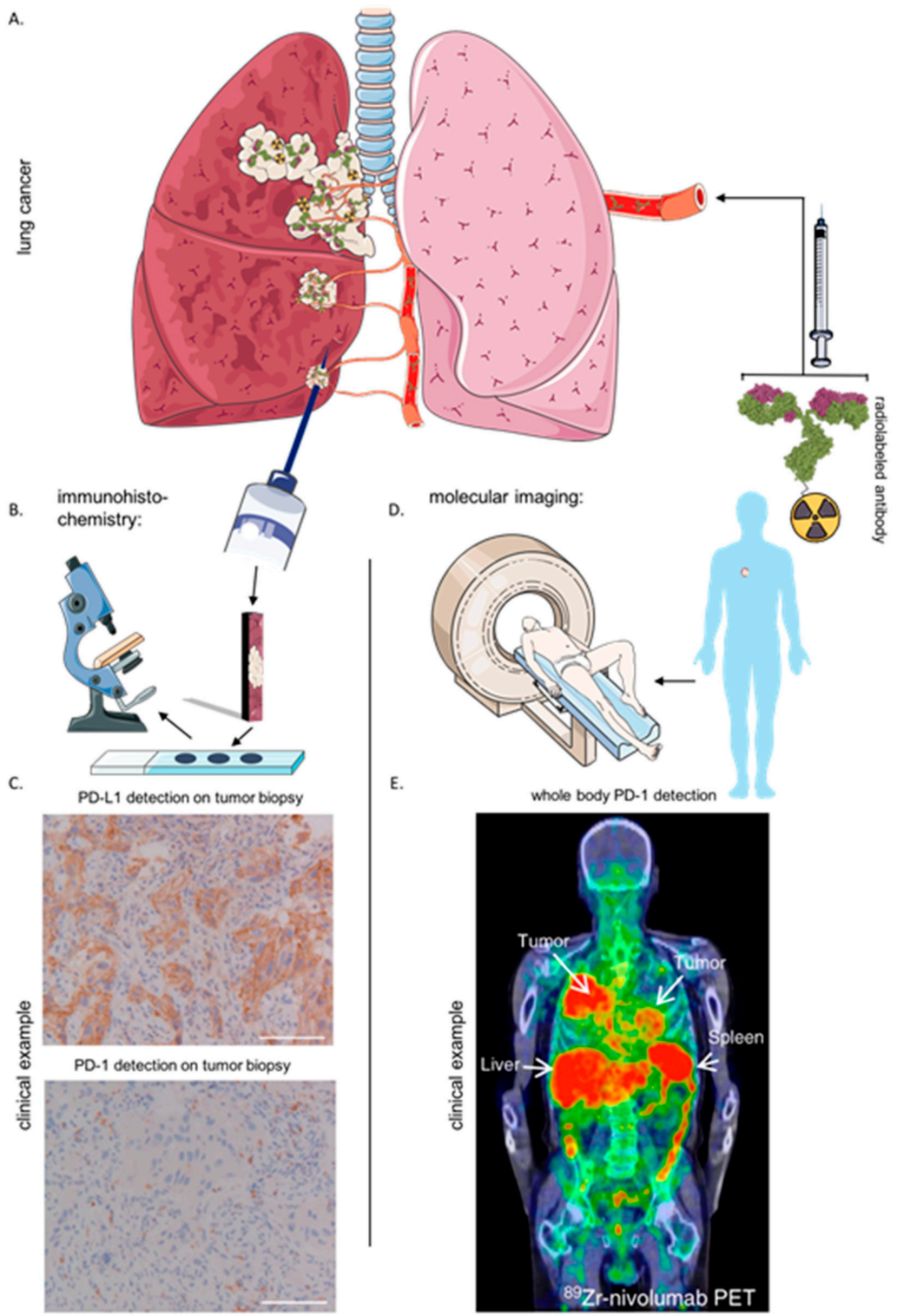

Figure 2. Comparison of IHC with molecular imaging for the detection of immune checkpoints. (A) Illustration of lung cancer that has metastasized to other regions. (B) Schematic representation of acquiring a biopsy of a tumor lesion and evaluation of biomarker expression using IHC. (C) Clinical example of PD-1/PD-L1 detection using IHC on a biopsy of NSCLC patient (adapted form Niemeijer et al. 2018 [91]). (D) Schematic representation of the intravenous injection of radiolabeled targeting moieties and the medical imaging devices used to visualize the tracer throughout the patient's body. (E) Clinical example of PD-1 detection using molecular imaging in a NSCLC patient with radiolabeled antibody Nivolumab (adapted form Niemeijer et al. 2018 [91]). Abbreviations: IHC, immunohistochemistry; NSCLC, non-small cell lung cancer; PD-1, programmed death-1; PD-L1, programmed death-ligand $1 ;{ }^{89} \mathrm{Zr}$, Zirconium ${ }^{89}$; PET, positron emission tomography. 


\section{Clinical Evaluation of LAG-3 Targeted Treatment in Cancer}

Since its discovery, many preclinical studies confirmed that the blockade of LAG3 could support anti-cancer immune responses, leading to a significant delay in tumor growth compared to control conditions [3,4,103-109]. Notwithstanding these preclinical data, more recent clinical research shows that the blockade of LAG-3 alone might not be an ideal treatment strategy. This might be explained by the ability of cancer cells to evade anti-tumor immune responses through a myriad of molecules. However, our lack of in-depth understanding of the mechanisms exploited by LAG-3 to suppress immune activity makes it difficult to explain the limited effect of LAG-3 blockade when used as a monotherapy. Notably, LAG-3 therapy is shown to be more effective when combined with other anti-cancer treatments. For example, Grosso et al. observed an increased number of tumor-infiltrating, activated $\mathrm{CD} 8^{+} \mathrm{T}$ cells when LAG-3 blockade was combined with tumor-associated antigen vaccination [103]. Moreover, co-blockade or genetic deletion of LAG-3 and PD-1 has shown strong therapeutic effects in various mouse tumor models $[3,104,105,109]$. Taken together, these observations encouraged pharmaceutical companies to implement LAG-3 as a promising therapeutic target in their pipeline.

As of today, 15 different LAG-3 blocking compounds have been evaluated in preclinical or clinical setting and purposed for the treatment of cancer. Table 1 summarizes these compounds and highlights their use for treating different cancer types as well as the clinical phase reached and the combination strategy that the developers have opted for. Most clinical trials are combining LAG-3 blockade with PD-1 or PD-L1 blocking compounds. Moreover, companies such as Fstar and Macrogenics are developing a mAb that simulatenously targets LAG-3 and PD-L1, or PD-1 respectively [110,111]. A schematic illustration of these compounds can be found in Figure 3.

Table 1. Table summarizing the 15 compounds under development for blockade of LAG-3.

\begin{tabular}{|c|c|c|c|c|c|c|}
\hline Name (Code) & Company & Format & Tumor Type & Study Phase & $\begin{array}{c}\text { National } \\
\text { Clinical Trial nr. }\end{array}$ & $\begin{array}{l}\text { Combined } \\
\text { with }\end{array}$ \\
\hline PRS-332 & $\begin{array}{l}\text { Pieris Pharma- } \\
\text { ceuticals }\end{array}$ & $\begin{array}{l}\text { LAG-3xPD-1 } \\
\text { bispecific } \\
\text { fusion protein }\end{array}$ & Solid & preclinical & / & / \\
\hline P13B02-3 & Agenus & IgG1 & Solid & preclinical & / & (PD-1) \\
\hline LBL-007 & $\begin{array}{l}\text { Nanjing Leads } \\
\text { Biolabs }\end{array}$ & $\begin{array}{l}\mathrm{scFv}_{\mathrm{F}}-\mathrm{IgG} 4 \\
\text { fusion }\end{array}$ & Solid & preclinical & / & $\begin{array}{c}\text { (mouse PD-1) } \\
\text { BE0146 BioXcell }\end{array}$ \\
\hline $\begin{array}{l}\text { Eftilagimod } \\
\text { alpha } \\
\text { (IMP321) }\end{array}$ & Immutep & $\begin{array}{l}\text { LAG-3 IgG1 Fc } \\
\text { fusion protein }\end{array}$ & $\begin{array}{c}\text { Solid, NSCLC, } \\
\text { HNSCC, Breast, } \\
\text { Melanoma }\end{array}$ & I \& II & $\begin{array}{l}03252938 \\
00351949, \\
00349934 \\
02676869 \\
03625323 \\
02614833\end{array}$ & $\begin{array}{c}\text { (PD-L1) } \\
\text { Avelumab } \\
\text { antibody, (PD-1) } \\
\text { Pem- } \\
\text { brolizumab } \\
\text { antibody }\end{array}$ \\
\hline $\begin{array}{l}\text { LAG525 } \\
\text { (IMP701) }\end{array}$ & $\begin{array}{c}\text { Novartis/Prima } \\
\text { Biomed }\end{array}$ & $\begin{array}{l}\text { Humanized } \\
\text { IgG4 }\end{array}$ & $\begin{array}{c}\text { Solid } \\
\text { (advanced) }\end{array}$ & I/II \& II & $\begin{array}{l}02460224 \\
03365791\end{array}$ & $\begin{array}{c}\text { (PD-1) } \\
\text { Spartalizumab } \\
\text { antibody } \\
\text { (PD-1) pem- }\end{array}$ \\
\hline MK-4280 & $\begin{array}{l}\text { Merck Sharp \& } \\
\text { Dohme }\end{array}$ & $\begin{array}{l}\text { Humanized } \\
\text { IgG4 }\end{array}$ & Hematological & $\mathrm{I} / \mathrm{II}$ & 03598608 & $\begin{array}{c}\text { (PD-1) pem- } \\
\text { brolizumab } \\
\text { (MK-3475) } \\
\text { antibody }\end{array}$ \\
\hline REGN3767 & $\begin{array}{l}\text { Regeneron } \\
\text { Pharmaceuti- } \\
\text { cals }\end{array}$ & $\begin{array}{l}\text { hinge- } \\
\text { stabilized } \\
\text { IgG4 }\end{array}$ & $\begin{array}{c}\text { Solid } \\
\text { (advanced) }\end{array}$ & I & 03005782 & $\begin{array}{c}\text { (PD-1) } \\
\text { Cemiplimab } \\
\text { (REGN2810) }\end{array}$ \\
\hline
\end{tabular}


Table 1. Cont.

\begin{tabular}{|c|c|c|c|c|c|c|}
\hline Name (Code) & Company & Format & Tumor Type & Study Phase & $\begin{array}{c}\text { National } \\
\text { Clinical Trial nr. }\end{array}$ & $\begin{array}{c}\text { Combined } \\
\text { with }\end{array}$ \\
\hline $\begin{array}{c}\text { Relatlimab } \\
\text { (BMS-986016) }\end{array}$ & $\begin{array}{l}\text { Bristol-Myers } \\
\text { Squibb }\end{array}$ & Human IgG4 & $\begin{array}{c}\text { Melanoma, } \\
\text { Hematological, } \\
\text { Glioblastoma, } \\
\text { Kidney, Lungs, } \\
\text { Colon }\end{array}$ & $\begin{array}{c}\text { I, I/Iia, II \& } \\
\text { II/III }\end{array}$ & $\begin{array}{l}02658981, \\
03335540, \\
02966548, \\
02061761, \\
01968109, \\
03459222, \\
02488759, \\
02996110, \\
02935634, \\
02750514, \\
02060188, \\
03470922\end{array}$ & $\begin{array}{c}\text { (PD-1) } \\
\text { Nivolumab } \\
\text { (BMS-936558) } \\
\text { antibody }\end{array}$ \\
\hline BI 754111 & $\begin{array}{l}\text { Boehringer } \\
\text { Ingelheim }\end{array}$ & $\begin{array}{l}\text { Humanized } \\
\text { IgG4 }\end{array}$ & $\begin{array}{l}\text { HN, NSCLC, } \\
\text { Solid } \\
\text { (metatstatic) }\end{array}$ & I \& II & $\begin{array}{l}03964233 \\
03697304\end{array}$ & $\begin{array}{c}\text { (PD-1) BI } \\
754091 \\
\text { antibody, } \\
\text { (VEGF/Ang2) } \\
\text { BI } 836880 \\
\text { bispecific } \\
\text { nanobody }\end{array}$ \\
\hline FS118 & $\begin{array}{c}\text { F-star } \\
\text { Therapeutics }\end{array}$ & $\begin{array}{c}\text { LAG-3 x PD-L1 } \\
\text { tetravalent } \\
\text { bispecific IgG1 } \\
\text { antibody }\end{array}$ & $\begin{array}{l}\text { Solid (advanced } \\
\text { \& metatstatic) }\end{array}$ & I & 03440437 & / \\
\hline $\begin{array}{l}\text { Tebotelimab } \\
\text { (MGD013) }\end{array}$ & MacroGenics & $\begin{array}{c}\text { LAG-3 } \times \text { PD-1 } \\
\text { bispecific IgG4k } \\
\text { antibody }\end{array}$ & $\begin{array}{c}\text { Solid, Cholan- } \\
\text { giocarcinoma, } \\
\text { Liver, Gastric } \\
\left(\text { HER-2 }^{+}\right), \\
\text {Breast } \\
\left(\text { HER-2 }^{+}\right), \\
\text {Oesophageal, } \\
\text { Haematological }\end{array}$ & I & 03219268 & $\begin{array}{c}\text { (HER2) } \\
\text { Margetuximab }\end{array}$ \\
\hline TSR-033 & Tesaro & $\begin{array}{l}\text { Humanized } \\
\text { IgG4 }\end{array}$ & $\begin{array}{c}\text { Solid } \\
\text { (advanced) }\end{array}$ & I & 03250832 & $\begin{array}{c}\text { (Tim-3) TSR-022 } \\
\text { antibody, (PD-1) } \\
\text { dostarlimab } \\
\text { (TSR-042) } \\
\text { antibody, } \\
\text { (VEGF-a) } \\
\text { Bevacizumab } \\
\text { antibody, } \\
\text { mFOLFOX6, } \\
\text { FOLFIRI }\end{array}$ \\
\hline INCAGN2385 & Incyte & t.b.a. & $\begin{array}{c}\text { Solid, } \\
\text { Melanoma }\end{array}$ & I & 04370704 & / \\
\hline Sym022 & Symphogen & Human Fc-inert & $\begin{array}{c}\text { Solid, } \\
\text { Lymphoma }\end{array}$ & I & $\begin{array}{l}03311412, \\
03489369\end{array}$ & $\begin{array}{c}\text { (PD-1) Sym021 } \\
\text { antibody, } \\
\text { (Tim-3) Sym023 } \\
\text { antibody }\end{array}$ \\
\hline $\mathrm{XmAb} 22841$ & Xencor & $\begin{array}{l}\text { LAG-3 x } \\
\text { CTLA-4 } \\
\text { bispecific } \\
\text { Fc-inert } \\
\text { antibody }\end{array}$ & Solid & I & 03849469 & $\begin{array}{l}\text { (PD-1) Pem- } \\
\text { brolizumab } \\
\text { antibody }\end{array}$ \\
\hline
\end{tabular}

Abbreviations: Ang2, angiotensin 2; CTLA-4, cytotoxic T lymphocyte-associated protein 4; Fc, fragment crystallizable; HER, human epidermal growth factor receptor; HN, head and neck cancer; Ig, immunoglobulin; NSCLC, non-small-cell lung cancer; PD-1, programmed death 1; PD-L1, programmed death-ligand 1; scFv, single-chain variable fragment; t.b.a., to be announced; TIM-3, T-cell immunoglobulin and mucin domain-3; VEGF, vascular endothelial growth factor; nr.; number. 


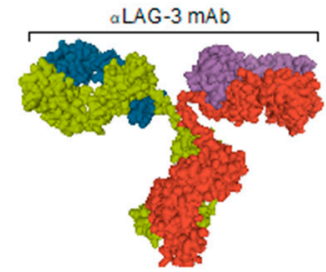

Relatlimab, LAG525, BI 754111, MK-4280, Sym022, TSR-033 ICAGN238, IM P731, RE GN3767, P13B02-3

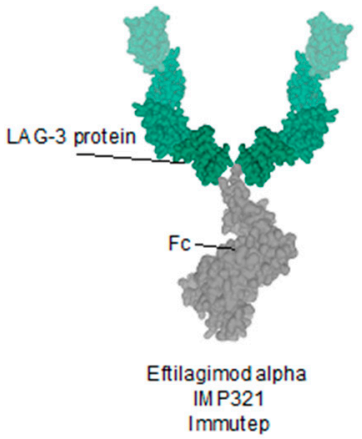

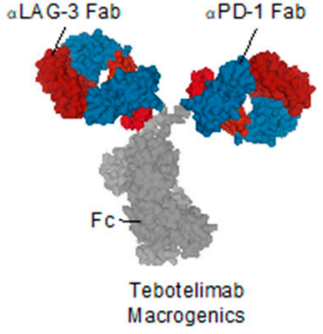
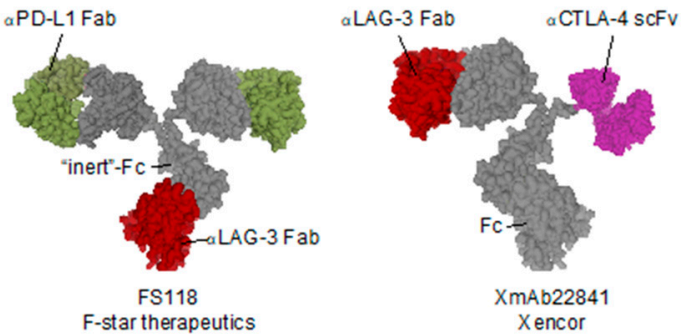

aLAG-3 single

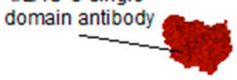

Nanobody 3132

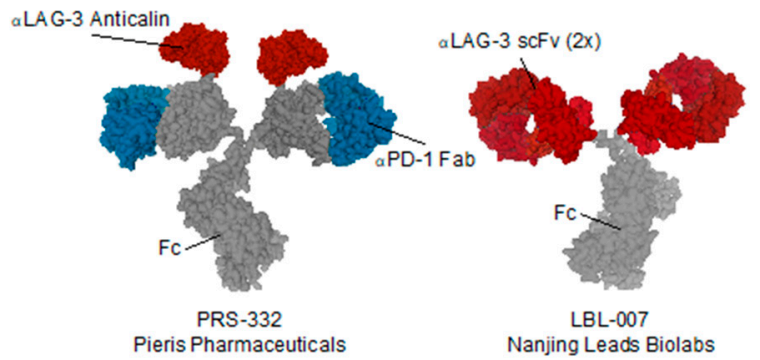

Figure 3. Schematic illustration of the structure and composition of LAG-3 targeting compounds evaluated as anti-cancer therapeutic and/or molecular imaging tracer. Abbreviations: Fab, antigen binding fragment; Fc, fragment crystallizable; scFv, single-chain variable fragment; $\alpha$-LAG-3, anti-LAG-3.

Although many preclinical studies show therapeutic synergy when combining LAG-3 and PD-1 blockade, only a few reported on its clinical efficacy. As an example, Relatlimab, a mAb targeting LAG-3 from BMS, is being evaluated in combination with Nivolumab (anti-PD-1) for its safety and efficacy in patients with advanced melanoma refractory to prior anti-PD-1 or anti-PD-L1 blocking treatments [112]. Based on the data reported during the 2017 ESMO congress, they observed an objective response in seven out of 61 patients $(11 \%)$ [8]. Moreover, prior to treatment, LAG-3 expression on tumor-associated immune cells was evaluated using IHC on a tumor biopsy. Retrospective analysis has demonstrated a response rate of $18 \%$ or $5 \%$ when efficacy is evaluated in the LAG- $3^{+}$group ( $>1 \%$ LAG-3 expression) versus LAG- $3^{-}$group ( $<1 \%$ LAG-3 expression), respectively. Additionally, an increase in response rate to $27 \%$ has been demonstrated in patient cohorts that scored LAG$3^{+}$and PD-L1 ${ }^{+}(>1 \%$ PD-L1 expression). These results highlight the importance of patient stratification to avoid the treatment of patients that are less likely to respond. Furthermore, Novartis/Prima Biomed combined Spartalizumab (anti-PD-1) with their LAG-3 targeting antibody LAG525. Durable responses were shown in 10 out of 121 patients $(9.9 \%)$ with various types of solid tumors [113].

Several first-in-class bispecific antibodies are undergoing phase I clinical trials. Macrogenics' Tebotelimab is a mAb harboring antigen binding fragments (Fab) targeting both PD-1 and LAG-3 [111]. Similarly, Pieris' compound PRS-332 harbors two Fab regions solely targeting PD-1 and two anticalins, which are engineered lipocalins that target LAG-3 [114]. Moreover, antibody FS118 from F-star therapeutics harbors an antigen-binding fragment targeting LAG-3 in its constant region, leaving the Fabs as PD-L1 targeting domains [110]. Xencors XmAb22841 is an antibody with one Fab targeting LAG-3, and the other Fab is replaced by a single-chain variable fragment (scFv) targeting CTLA-4 [115]. Future reports on these constructs are awaited to gather insight on their actual therapeutic efficacy.

In addition to the use of antibodies, other LAG-3-targeting agents have been evaluated for the treatment of cancer. Molecule IMP321 is a fusion protein consisting of extracellular LAG-3 regions coupled to an Fc-region of IgG [116]. IMP321 was previously shown to activate APCs through interaction with MHC-II, which is present on their membrane $[117,118]$. Although preclinical work was able to show an increase in IL-12 and tumor necrosis alpha 
(TNF- $\alpha$ ) production after administration of IMP321, its clinical efficacy was only minimal even when combined with other types of treatments [119-121].

We expect that all studies, once completed, will give more insight in the biological properties of LAG-3, which will ultimately help rationalize the use of these LAG-3 targeting agents for the treatment of cancer patients.

\section{Conclusions and Perspectives}

Although the biological processes of LAG-3 are yet to be fully discovered, more than 15 different moieties targeting this ICP have been developed. Moreover, it has been suggested that accurate patient stratification could help select patients that are more likely to respond. Consequently, different research groups are untangling the advantages of using molecular imaging to detect whole body target expression over the use of IHC. Although not yet proved for the ICP LAG-3 in particular, the advantage of using molecular imaging over IHC has already been demonstrated for the ICP PD-L1 [90,91]. However, the visualization of ICPs using radiolabeled antibodies is not practical. Therefore, smaller sized nanobodies with better penetration capacities and more rapid clearance are expected to be an ideal alternative. Combinatory treatments that incorporate the blockade of LAG-3 are viewed as a promising approach to improve current immunotherapies. Indeed, preclinical work in the field of immuno-oncology indicates that combination immunotherapies that include LAG-3 blockade could have synergic effects on anti-cancer immune responses. Additionally, early clinical data of BMS's LAG-3 targeting antibody Relatlimab showed an improved OS of cancer patients when combined with the PD-1 blocking $\mathrm{mAb}$ Nivolumab. These preclinical and clinical results catalyzed an excitement for LAG-3 blockade that is spilling into several pharmaceutical companies, hence encouraging the further development of moieties that bind and block LAG-3.

Author Contributions: Writing—Original Draft Preparation, Q.L.; Writing-Review \& Editing, Q.L., M.K., N.D., K.B.; Funding Acquisition. All authors have read and agreed to the published version of the manuscript.

Funding: This research was financially supported by the Belgian Foundation against Cancer; Kom op tegen Kanker (Stand-up to Cancer), the Flemish cancer society; the Research Foundation Flanders (FWO-V; 1501019N \& I001618N). Q. Lecocq has been funded via an "Emmanuel Vanderscheuren" award and is a FWO-SB fellow (1S24218N). Marleen Keyaerts is a senior clinical investigator at FWO-Vlaanderen.

Conflicts of Interest: Marleen Keyaerts received research funding from Camel-IDS. Karine Breckpot, Nick Devoogdt and Marleen Keyaerts have patents on the use of nanobodies for imaging and therapy. Nick Devoogdt and Marleen Keyaerts have ownership in AbScint, which leverages nanobody imaging tracers into clinical application.

$\begin{array}{ll}\text { Abbreviations } & \\ \text { ICP } & \text { immune checkpoint } \\ \text { mAb } & \text { monoclonal antibody } \\ \text { CTLA-4 } & \text { cytotoxic T lymphocyte associated protein-4 } \\ \text { PD-1 } & \text { programmed deat-1 } \\ \text { TIL } & \text { tumor-infiltrating lymphocyte } \\ \text { irAEs } & \text { immune-related adverse events } \\ \text { LAG-3 } & \text { lymphocyte activating gene-3 } \\ \text { TME } & \text { tumor microenvironment } \\ \text { IHC } & \text { immunohistochemistry } \\ \text { Ig } & \text { immunoglobulin } \\ \text { MHC-II } & \text { major histocompatibility complex } \\ \text { pMHC-II } & \text { peptide loaded MHC-II } \\ \text { APC } & \text { antigen-presenting cell } \\ \text { Gal-3 } & \text { galectin-3 }\end{array}$




$\begin{array}{ll}\text { LSECtin } & \text { liver sinusoidal endothelial cell lectin } \\ \text { FGL-1 } & \text { fibrinogen like protein 1 } \\ \text { IFN- } \gamma & \text { Interferon gamma } \\ \text { IL } & \text { Interleukin } \\ \text { Treg } & \text { regulatory T cell } \\ \text { NK } & \text { natural killer cell } \\ \text { pDC } & \text { plasmacytoid dendritic cell } \\ \text { DC } & \text { dendritic cell } \\ \text { TAM } & \text { tumor-associated macrophage } \\ \text { TOX } & \text { thymocyte selection-associated high mobility group box protein } \\ \text { NFAT } & \text { nuclear factor of activated T cells } \\ \text { NR4A } & \text { nuclear receptor subfamily 4, group A } \\ \text { TGF- } \beta & \text { transforming growth factor beta } \\ \text { EGR2 } & \text { early growth response gene 2 } \\ \text { ITIM } & \text { immunoreceptor tyrosine-based inhibitory motifs } \\ \text { LAP } & \text { LAG-3-associated protein } \\ \text { NSCLC } & \text { non-small-cell lung cancer } \\ \text { sLAG-3 } & \text { soluble LAG-3 } \\ \text { OS } & \text { overall survival } \\ \text { Zr } 89 & \text { Zirconium } \\ \text { Fab } & \text { antigen binding fragment } \\ \text { scFv } & \text { single-chain variable fragment } \\ \text { TNF- } \alpha & \text { tumor necrosis factor alpha } \\ & \end{array}$

\section{References}

1. Bray, F.; Ferlay, J.; Soerjomataram, I.; Siegel, R.L.; Torre, L.A.; Jemal, A. Global cancer statistics 2018: GLOBOCAN estimates of incidence and mortality worldwide for 36 cancers in 185 countries. CA Cancer J. Clin. 2018, 68, 394-424. [CrossRef] [PubMed]

2. Awad, R.M.; De Vlaeminck, Y.; Maebe, J.; Goyvaerts, C.; Breckpot, K. Turn Back the TIMe: Targeting Tumor Infiltrating Myeloid Cells to Revert Cancer Progression. Front. Immunol. 2018, 9, 1977. [CrossRef] [PubMed]

3. Woo, S.-R.; Turnis, M.E.; Goldberg, M.V.; Bankoti, J.; Selby, M.; Nirschl, C.J.; Bettini, M.L.; Gravano, D.M.; Vogel, P.; Liu, C.L.; et al. Immune Inhibitory Molecules LAG-3 and PD-1 Synergistically Regulate T-cell Function to Promote Tumoral Immune Escape. Cancer Res. 2011, 72, 917-927. [CrossRef] [PubMed]

4. Matsuzaki, J.; Gnjatic, S.; Mhawech-Fauceglia, P.; Beck, A.; Miller, A.; Tsuji, T.; Eppolito, C.; Qian, F.; Lele, S.; Shrikant, P.; et al. Tumor-infiltrating NY-ESO-1-specific CD8+T cells are negatively regulated by LAG-3 and PD-1 in human ovarian cancer. Proc. Natl. Acad. Sci. USA 2010, 107, 7875-7880. [CrossRef]

5. Broos, K.; Lecocq, Q.; Xavier, C.; Bridoux, J.; Nguyen, T.T.; Corthals, J.; Schoonooghe, S.; Lion, E.; Raes, G.; Keyaerts, M.; et al. Evaluating a Single Domain Antibody Targeting Human PD-L1 as a Nuclear Imaging and Therapeutic Agent. Cancers 2019, 11, 872. [CrossRef]

6. Nguyen, L.T.; Ohashi, P.S. Clinical blockade of PD1 and LAG3-Potential mechanisms of action. Nat. Rev. Immunol. 2015, 15, 45-56. [CrossRef]

7. Ascierto, P.A.; Melero, I.; Bhatia, S.; Bono, P.; Sanborn, R.E.; Lipson, E.J.; Callahan, M.K.; Gajewski, T.; Gomez-Roca, C.A.; Hodi, F.S.; et al. Initial efficacy of anti-lymphocyte activation gene-3 (anti-LAG-3; BMS-986016) in combination with nivolumab (nivo) in pts with melanoma (MEL) previously treated with anti-PD-1/PD-L1 therapy. J. Clin. Oncol. 2017, 35, 9520. [CrossRef]

8. European Society for Medical Oncology. ESMO 2017 Congress Scientific Meeting Report [Internet]. 2007. Available online: https: / / oncologypro.esmo.org/content/download/126251/2385263/file/ESMO-2017-Congress-Scientific-Meeting-Report.pdf (accessed on 3 November 2020).

9. Broos, K.; Lecocq, Q.; Raes, G.; Devoogdt, N.; Keyaerts, M.; Breckpot, K. Noninvasive imaging of the PD-1:PD-L1 immune checkpoint: Embracing nuclear medicine for the benefit of personalized immunotherapy. Theranostics 2018, 8, 3559-3570. [CrossRef]

10. Topalian, S.L.; Hodi, F.S.; Brahmer, J.R.; Gettinger, S.N.; Smith, D.C.; McDermott, D.F.; Powderly, J.; Carvajal, R.; Sosman, J.; Atkins, M.; et al. Safety, activity, and immune correlates of anti-PD-1 antibody in cancer. N. Engl. J. Med. 2012, 366, 2443-2454. [CrossRef]

11. Brahmer, J.R.; Drake, C.G.; Wollner, I.; Powderly, J.D.; Picus, J.; Sharfman, W.H.; Stankevich, E.; Pons, A.; Salay, T.M.; McMiller, T.L.; et al. Phase I Study of Single-Agent Anti-Programmed Death-1 (MDX-1106) in Refractory Solid Tumors: Safety, Clinical Activity, Pharmacodynamics, and Immunologic Correlates. J. Clin. Oncol. 2010, 28, 3167-3175. [CrossRef]

12. Yarchoan, M.; Hopkins, A.; Jaffee, E.M. Tumor Mutational Burden and Response Rate to PD-1 Inhibition. N. Engl. J. Med. 2017, 377, 2500-2501. [CrossRef] [PubMed]

13. Tang, H.; Liang, Y.; Anders, R.A.; Taube, J.M.; Qiu, X.; Mulgaonkar, A.; Liu, X.; Harrington, S.M.; Guo, J.; Xin, Y.; et al. PD-L1 on host cells is essential for PD-L1 blockade-mediated tumor regression. J. Clin. Investig. 2018, 128, 580-588. [CrossRef] [PubMed] 
14. Triebel, F.; Jitsukawa, S.; Baixeras, E.; Roman-Roman, S.; Genevee, C.; Viegas-Pequignot, E.; Hercend, T. LAG-3, a novel lymphocyte activation gene closely related to CD4. J. Exp. Med. 1990, 171, 1393-1405. [CrossRef] [PubMed]

15. Huard, B.; Prigent, P.; Tournier, M.; Bruniquel, D.; Triebel, F. CD4/major histocompatibility complex class II interaction analyzed with CD4- and lymphocyte activation gene-3 (LAG-3)-Ig fusion proteins. Eur. J. Immunol. 1995, 25, 2718-2721. [CrossRef]

16. Kim, S.-S.; Kim, S.-H.; Kang, H.-S.; Chung, H.Y.; Choi, I.; Cheon, Y.-P.; Lee, K.H.; Lee, D.-M.; Park, J.; Lee, S.Y.; et al. Molecular cloning and expression analysis of pig lymphocyte activation gene-3 (LAG-3; CD223). Veter-Immunol. Immunopathol. 2010, 133, 72-79. [CrossRef]

17. Dijkstra, J.M.; Somamoto, T.; Moore, L.; Hordvik, I.; Ototake, M.; Fischer, U. Identification and characterization of a second CD4-like gene in teleost fish. Mol. Immunol. 2006, 43, 410-419. [CrossRef]

18. Huard, B.; Mastrangeli, R.; Prigent, P.; Bruniquel, D.; Donini, S.; El-Tayar, N.; Maigret, B.; Dréano, M.; Triebel, F. Characterization of the major histocompatibility complex class II binding site on LAG-3 protein. Proc. Natl. Acad. Sci. USA 1997, 94, 5744-5749. [CrossRef]

19. Workman, C.J.; Rice, D.S.; Dugger, K.J.; Kurschner, C.; Vignali, D.A.A. Phenotypic analysis of the murine CD4-related glycoprotein, CD223 (LAG-3). Eur. J. Immunol. 2002, 32, 2255-2263. [CrossRef]

20. Neefjes, J.; Jongsma, M.L.M.; Paul, P.; Bakke, O. Towards a systems understanding of MHC class I and MHC class II antigen presentation. Nat. Rev. Immunol. 2011, 11, 823-836. [CrossRef]

21. Maruhashi, T.; Okazaki, I.-M.; Sugiura, D.; Takahashi, S.; Maeda, T.K.; Shimizu, K.; Okazaki, T. LAG-3 inhibits the activation of CD4+ T cells that recognize stable pMHCII through its conformation-dependent recognition of pMHCII. Nat. Immunol. 2018, 19, 1415-1426. [CrossRef]

22. Liu, W.; Tang, L.; Zhang, G.; Wei, H.; Cui, Y.; Guo, L.; Gou, Z.; Chen, X.; Jiang, D.; Zhu, Y.; et al. Characterization of a novel C-type lectin-like gene, LSECtin: Demonstration of carbohydrate binding and expression in sinusoidal endothelial cells of liver and lymph node. J. Biol. Chem. 2004, 279, 18748-18758. [CrossRef] [PubMed]

23. Xu, F.; Liu, J.; Liu, D.; Liu, B.; Wang, M.; Hu, Z.; Du, X.; Tang, L.; He, F. LSECtin Expressed on Melanoma Cells Promotes Tumor Progression by Inhibiting Antitumor T-cell Responses. Cancer Res. 2014, 74, 3418-3428. [CrossRef] [PubMed]

24. Kouo, T.S.; Huang, L.; Pucsek, A.B.; Cao, M.; Solt, S.; Armstrong, T.D.; Jaffee, E.M. Galectin-3 Shapes Antitumor Immune Responses by Suppressing CD8+ T Cells via LAG-3 and Inhibiting Expansion of Plasmacytoid Dendritic Cells. Cancer Immunol. Res. 2015, 3, 412-423. [CrossRef] [PubMed]

25. Ruvolo, P.P. Galectin 3 as a guardian of the tumor microenvironment. Biochim. Biophys. Acta (BBA) Bioenerg. 2016, 1863, 427-437. [CrossRef] [PubMed]

26. Wang, J.; Sanmamed, M.F.; Datar, I.; Su, T.T.; Ji, L.; Sun, J.; Chen, Y.; Zhu, G.; Yin, W.; Zheng, L.; et al. Faculty Opinions recommendation of Fibrinogen-like Protein 1 Is a Major Immune Inhibitory Ligand of LAG-3. Cell 2019, 176, 334-347. [CrossRef] [PubMed]

27. Demeure, C.; Wolfers, J.; Martin-Garcia, N.; Gaulard, P.; Triebel, F. T Lymphocytes infiltrating various tumour types express the MHC class II ligand lymphocyte activation gene-3 (LAG-3): Role of LAG-3/MHC class II interactions in cell-cell contacts. Eur. J. Cancer 2001, 37, 1709-1718. [CrossRef]

28. Okazaki, T.; Okazaki, I.-M.; Wang, J.; Sugiura, D.; Nakaki, F.; Yoshida, T.; Kato, Y.; Fagarasan, S.; Muramatsu, M.; Eto, T.; et al. PD-1 and LAG-3 inhibitory co-receptors act synergistically to prevent autoimmunity in mice. J. Exp. Med. 2011, 208, 395-407. [CrossRef]

29. Okamura, T.; Fujio, K.; Shibuya, M.; Sumitomo, S.; Shoda, H.; Sakaguchi, S.; Yamamoto, K. CD4+CD25-LAG3+ regulatory T cells controlled by the transcription factor Egr-2. Proc. Natl. Acad. Sci. USA 2009, 106, 13974-13979. [CrossRef]

30. Byun, H.; Jung, W.; Lee, D.; Kim, S.; Park, C.; Chung, H.Y.; Chun, T. Proliferation of activated CD1d-restricted NKT cells is down-modulated by lymphocyte activation gene-3 signaling via cell cycle arrest in S phase. Cell Biol. Int. 2007, 31, $257-262$. [CrossRef]

31. Kisielow, M.; Kisielow, J.; Capoferri-Sollami, G.; Karjalainen, K. Expression of lymphocyte activation gene 3 (LAG-3) on B cells is induced by T cells. Eur. J. Immunol. 2005, 35, 2081-2088. [CrossRef]

32. Merino, A.; Zhang, B.; Dougherty, P.; Luo, X.; Wang, J.; Blazar, B.R.; Miller, J.S.; Cichocki, F. Chronic stimulation drives human NK cell dysfunction and epigenetic reprograming. J. Clin. Investig. 2019, 129, 3770-3785. [CrossRef] [PubMed]

33. Workman, C.J.; Wang, Y.; El Kasmi, K.C.; Pardoll, D.M.; Murray, P.J.; Drake, C.G.; Vignali, D.A.A. LAG-3 Regulates Plasmacytoid Dendritic Cell Homeostasis. J. Immunol. 2009, 182, 1885-1891. [CrossRef] [PubMed]

34. Camisaschi, C.; De Filippo, A.; Beretta, V.; Vergani, B.; Villa, A.; Vergani, E.; Santinami, M.; Cabras, A.D.; Arienti, F.; Triebel, F.; et al. Alternative Activation of Human Plasmacytoid DCs In Vitro and in Melanoma Lesions: Involvement of LAG-3. J. Investig. Dermatol. 2014, 134, 1893-1902. [CrossRef] [PubMed]

35. Keane, C.; Law, S.C.; Gould, C.M.; Birch, S.; Sabdia, M.B.; De Long, L.M.; Thillaiyampalam, G.; Abro, E.; Tobin, J.W.; Tan, X.; et al. LAG3: A novel immune checkpoint expressed by multiple lymphocyte subsets in diffuse large B-cell lymphoma. Blood Adv. 2020, 4, 1367-1377. [CrossRef]

36. Kim, Y.J.; Won, C.H.; Lee, M.W.; Choi, J.-H.; Chang, S.-E.; Lee, W.J. Correlation Between Tumor-Associated Macrophage and Immune Checkpoint Molecule Expression and Its Prognostic Significance in Cutaneous Melanoma. J. Clin. Med. 2020, 9, 2500. [CrossRef] [PubMed] 
37. Mao, X.; Ou, M.T.; Karuppagounder, S.S.; Kam, T.I.; Yin, X.; Xiong, Y.; Ge, P.; Umanah, G.E.; Brahmachari, S.; Shin, J.-H.; et al. Pathological $\alpha$-synuclein transmission initiated by binding lymphocyte-activation gene 3. Science 2016, 353, aah3374. [CrossRef] [PubMed]

38. Wu, J.; Zhang, H.; Shi, X.; Xiao, X.; Fan, Y.; Minze, L.J.; Wang, J.; Ghobrial, R.M.; Xia, J.; Sciammas, R.; et al. Ablation of Transcription Factor IRF4 Promotes Transplant Acceptance by Driving Allogenic CD4+ T Cell Dysfunction. Immunity 2017, 47, 1114-1128.e6. [CrossRef]

39. Chen, J.; López-Moyado, I.F.; Seo, H.; Lio, C.W.J.; Hempleman, L.J.; Sekiya, T.; Yoshimura, A.; Scott-Browne, J.P.; Rao, A. NR4A transcription factors limit CAR T cell function in solid tumours. Nature 2019, 567, 530-534. [CrossRef]

40. Khan, O.; Giles, J.R.; McDonald, S.; Manne, S.; Ngiow, S.F.; Patel, K.P.; Werner, M.T.; Huang, A.C.; Alexander, K.A.; Wu, J.E.; et al. TOX transcriptionally and epigenetically programs CD8+ T cell exhaustion. Nature 2019, 571, 211-218. [CrossRef]

41. Liu, X.; Wang, Y.; Lu, H.; Li, J.; Yan, X.; Xiao, M.; Huang, R.; Wu, J.; Zhao, Q.; Wu, Q.; et al. Faculty Opinions recommendation of Genome-wide analysis identifies NR4A1 as a key mediator of T cell dysfunction. Nature 2019, 567, 525-529. [CrossRef]

42. Martinez, G.J.; Pereira, R.M.; Äijö, T.; Kim, E.Y.; Marangoni, F.; Pipkin, M.E.; Togher, S.; Heissmeyer, V.; Zhang, Y.C.; Crotty, S.; et al. The Transcription Factor NFAT Promotes Exhaustion of Activated CD8 + T Cells. Immunity 2015, 42, 265-278. [CrossRef] [PubMed]

43. Seo, H.; Chen, J.; González-Avalos, E.; Samaniego-Castruita, D.; Das, A.; Wang, Y.H.; López-Moyado, I.F.; Georges, R.O.; Zhang, W.; Onodera, A.; et al. TOX and TOX2 transcription factors cooperate with NR4A transcription factors to impose CD8+ T cell exhaustion. Proc. Natl. Acad. Sci. USA 2019, 116, 12410-12415. [CrossRef] [PubMed]

44. Scott, A.C.; Dündar, F.; Zumbo, P.; Chandran, S.S.; Klebanoff, C.A.; Shakiba, M.; Trivedi, P.; Menocal, L.; Appleby, H.; Camara, S.J.; et al. TOX is a critical regulator of tumour-specific T cell differentiation. Nature 2019, 571, 270-274. [CrossRef] [PubMed]

45. Bae, J.; Lee, S.J.; Park, C.-G.; Lee, Y.S.; Chun, T. Trafficking of LAG-3 to the Surface on Activated T Cells via Its Cytoplasmic Domain and Protein Kinase C Signaling. J. Immunol. 2014, 193, 3101-3112. [CrossRef] [PubMed]

46. Li, N.; Wang, Y.; Forbes, K.; Vignali, K.M.; Heale, B.S.; Saftig, P.; Hartmann, D.; A Black, R.; Rossi, J.J.; Blobel, C.P.; et al. Metalloproteases regulate T-cell proliferation and effector function via LAG-3. EMBO J. 2007, 26, 494-504. [CrossRef]

47. Rouse, B. Faculty Opinions recommendation of Role of LAG-3 in regulatory T cells. Immunity 2004, 21, 503-513. [CrossRef]

48. Gagliani, N.; Magnani, C.F.; Huber, S.; Gianolini, M.E.; Pala, M.; Licona-Limon, P.; Guo, B.; Herbert, D.R.; Bulfone, A.; Trentini, F.; et al. Coexpression of CD49b and LAG-3 identifies human and mouse T regulatory type 1 cells. Nat. Med. 2013, 19, 739-746. [CrossRef]

49. Okamura, T.; Sumitomo, S.; Morita, K.; Iwasaki, Y.; Inoue, M.; Nakachi, S.; Komai, T.; Shoda, H.; Miyazaki, J.-I.; Fujio, K.; et al. TGF-33-expressing CD4+CD25-LAG3+ regulatory T cells control humoral immune responses. Nat. Commun. 2015, 6, 6329. [CrossRef]

50. Li, M.O.; Rudensky, A.Y. T cell receptor signalling in the control of regulatory T cell differentiation and function. Nat. Rev. Immunol. 2016, 16, 220-233. [CrossRef]

51. Huard, B.; Tournier, M.; Triebel, F. LAG-3 does not define a specific mode of natural killing in human. Immunol. Lett. 1998, 61, 109-112. [CrossRef]

52. Kritikou, J.S.; Dahlberg, C.I.M.; Baptista, M.A.P.; Wagner, A.K.; Banerjee, P.P.; Gwalani, L.A.; Poli, C.; Panda, S.K.; Kärre, K.; Kaech, S.M.; et al. IL-2 in the tumor microenvironment is necessary for Wiskott-Aldrich syndrome protein deficient NK cells to respond to tumors in vivo. Sci. Rep. 2016, 6, 30636. [CrossRef] [PubMed]

53. Sun, H.; Sun, C.; Xiao, W. Expression regulation of co-inhibitory molecules on human natural killer cells in response to cytokine stimulations. Cytokine 2014, 65, 33-41. [CrossRef] [PubMed]

54. Maeda, T.K.; Sugiura, D.; Okazaki, I.-M.; Maruhashi, T.; Okazaki, T. Atypical motifs in the cytoplasmic region of the inhibitory immune co-receptor LAG-3 inhibit T cell activation. J. Biol. Chem. 2019, 294, 6017-6026. [CrossRef]

55. Iouzalen, N.; Andreae, S.; Hannier, S.; Triebel, F. LAP, a lymphocyte activation gene-3 (LAG-3)-associated protein that binds to a repeated EP motif in the intracellular region of LAG-3, may participate in the down-regulation of the CD3/TCR activation pathway. Eur. J. Immunol. 2001, 31, 2885-2891. [CrossRef]

56. Bos, R.; Marquardt, K.L.; Cheung, J.; Sherman, L.A. Functional differences between low- and high-affinity CD8+T cells in the tumor environment. OncoImmunology 2012, 1, 1239-1247. [CrossRef]

57. Camisaschi, C.; Casati, C.; Rini, F.; Perego, M.; De Filippo, A.; Triebel, F.; Parmiani, G.; Belli, F.; Rivoltini, L.; Castelli, C. LAG-3 Expression Defines a Subset of CD4+CD25highFoxp3+ Regulatory T Cells That Are Expanded at Tumor Sites. J. Immunol. 2010 184, 6545-6551. [CrossRef]

58. Wei, T.; Zhang, J.; Qin, Y.; Wu, Y.; Zhu, L.; Lu, L.; Tang, G.; Shen, Q. Increased expression of immunosuppressive molecules on intratumoral and circulating regulatory T cells in non-small-cell lung cancer patients. Am. J. Cancer Res. 2015, 5, $2190-2201$.

59. Liang, B.; Workman, C.; Lee, J.; Chew, C.; Dale, B.M.; Colonna, L.; Flores, M.; Li, N.; Schweighoffer, E.; Greenberg, S.; et al. Regulatory T Cells Inhibit Dendritic Cells by Lymphocyte Activation Gene-3 Engagement of MHC Class II. J. Immunol. 2008, 180, 5916-5926. [CrossRef]

60. Lino, A.C.; Dang, V.D.; Lampropoulou, V.; Welle, A.; Joedicke, J.; Pohar, J.; Simon, Q.; Thalmensi, J.; Baures, A.; Flühler, V.; et al. LAG-3 Inhibitory Receptor Expression Identifies Immunosuppressive Natural Regulatory Plasma Cells. Immunity 2018, 49, 120-133.e9. [CrossRef] [PubMed] 
61. Hensler, M.; Kasikova, L.; Fiser, K.; Rakova, J.; Skapa, P.; Laco, J.; Lanickova, T.; Pecen, L.; Truxova, I.; Vosahlikova, S.; et al. M2-like macrophages dictate clinically relevant immunosuppression in metastatic ovarian cancer. J. Immunother. Cancer 2020, 8 , e000979. [CrossRef]

62. Lienhardt, C.; Azzurri, A.; Amedei, A.; Fielding, K.; Sillah, J.; Sow, O.Y.; Bah, B.; Benagiano, M.; Diallo, A.; Manetti, R.; et al. Active tuberculosis in Africa is associated with reduced Th1 and increased Th2 activity in vivo. Eur. J. Immunol. 2002, 32, 1605-1613. [CrossRef]

63. Triebel, F. LAG-3: A regulator of T-cell and DC responses and its use in therapeutic vaccination. Trends Immunol. 2003, 24, 619-622. [CrossRef] [PubMed]

64. Annunziato, F.; Manetti, R.; Tomasévic, I.; Giudizi, M.G.; Biagiotti, R.; Giannò, V.; Germano, P.; Mavilia, C.; Maggi, E.; Romagnani, $\mathrm{S}$. Expression and release of LAG-3-encoded protein by human CD4+ T cells are associated with IFN-gamma production. FASEB J. 1996, 10, 769-776. [CrossRef] [PubMed]

65. Long, L.; Zhang, X.; Chen, F.; Pan, Q.; Phiphatwatchara, P.; Zeng, Y.; Chen, H. The promising immune checkpoint LAG-3: From tumor microenvironment to cancer immunotherapy. Genes Cancer 2018, 9, 176-189. [CrossRef]

66. Solinas, C.; Migliori, E.; De Silva, P.; Willard-Gallo, K. LAG3: The Biological Processes That Motivate Targeting This Immune Checkpoint Molecule in Human Cancer. Cancers 2019, 11, 1213. [CrossRef]

67. Andrews, L.P.; Marciscano, A.E.; Drake, C.G.; Vignali, D.A. LAG3 (CD223) as a cancer immunotherapy target. Immunol. Rev. 2017, 276, 80-96. [CrossRef]

68. Giraldo, N.A.; Becht, E.; Pagès, F.; Skliris, G.P.; Verkarre, V.; Vano, Y.; Méjean, A.; Saint-Aubert, N.; Lacroix, L.; Natario, I.; et al. Orchestration and Prognostic Significance of Immune Checkpoints in the Microenvironment of Primary and Metastatic Renal Cell Cancer. Clin. Cancer Res. 2015, 21, 3031-3040. [CrossRef]

69. Lv, K.; Li, R.; Cao, Y.; Gu, Y.; Liu, X.; He, X.; Jin, K.; Fang, H.; Fei, Y.; Shi, M.; et al. LAG-3 expression associates with poor prognosis and immunoevasive contexture in EBV-positive and MLH1-defective gastric cancer patients. Int. J. Cancer 2020, 148, 759-768. [CrossRef]

70. Zeng, H.; Zhou, Q.; Wang, Z.; Zhang, H.; Liu, Z.; Huang, Q.; Wang, J.; Chang, Y.; Bai, Q.; Xia, Y.; et al. Stromal LAG-3+ cells infiltration defines poor prognosis subtype muscle-invasive bladder cancer with immunoevasive contexture. J. Immunother. Cancer 2020, 8, e000651. [CrossRef]

71. Llosa, N.J.; Cruise, M.; Tam, A.; Wicks, E.C.; Hechenbleikner, E.M.; Taube, J.M.; Blosser, R.L.; Fan, H.; Wang, H.; Luber, B.S.; et al. The Vigorous Immune Microenvironment of Microsatellite Instable Colon Cancer Is Balanced by Multiple Counter-Inhibitory Checkpoints. Cancer Discov. 2015, 5, 43-51. [CrossRef]

72. Shapiro, M.; Herishanu, Y.; Katz, B.-Z.; Dezorella, N.; Sun, C.; Kay, S.; Polliack, A.; Avivi, I.; Wiestner, A.; Perry, C. Lymphocyte activation gene 3: A novel therapeutic target in chronic lymphocytic leukemia. Haematologica 2017, 102, 874-882. [CrossRef]

73. Chen, C.; Liang, C.; Wang, S.; Chio, C.L.; Zhang, Y.; Zeng, C.; Chen, S.; Wang, C.; Li, Y. Expression patterns of immune checkpoints in acute myeloid leukemia. J. Hematol. Oncol. 2020, 13, 28. [CrossRef]

74. Yang, Z.-Z.; Kim, H.J.; Villasboas, J.C.; Chen, Y.-P.; Price-Troska, T.; Jalali, S.; Wilson, M.; Novak, A.J.; Ansell, S.M. Expression of LAG-3 defines exhaustion of intratumoral PD-1+ T cells and correlates with poor outcome in follicular lymphoma. Oncotarget 2017, 8, 61425-61439. [CrossRef] [PubMed]

75. Li, F.-J.; Zhang, Y.; Jin, G.-X.; Yao, L.; Wu, D.-Q. Expression of LAG-3 is coincident with the impaired effector function of HBV-specific CD8+ T cell in HCC patients. Immunol. Lett. 2013, 150, 116-122. [CrossRef] [PubMed]

76. Guo, M.; Yuan, F.; Qi, F.; Sun, J.; Rao, Q.; Zhao, Z.; Huang, P.; Fang, T.; Yang, B.; Xia, J. Expression and clinical significance of LAG-3, FGL1, PD-L1 and CD8+T cells in hepatocellular carcinoma using multiplex quantitative analysis. J. Transl. Med. 2020, 18, 306. [CrossRef] [PubMed]

77. Jie, H.-B.; Gildenerleapman, N.; Li, J.; Srivastava, R.M.; Gibson, S.P.; Whiteside, T.L.; Ferris, R.L. Intratumoral regulatory T cells upregulate immunosuppressive molecules in head and neck cancer patients. Br. J. Cancer 2013, 109, 2629-2635. [CrossRef] [PubMed]

78. Wang, W.; Chen, D.; Zhao, Y.; Zhao, T.; Wen, J.; Mao, Y.; Chen, C.; Sang, Y.; Zhang, Y.; Chen, Y. Characterization of LAG-3, CTLA-4, and CD8+ TIL density and their joint influence on the prognosis of patients with esophageal squamous cell carcinoma. Ann. Transl. Med. 2019, 7, 776. [CrossRef] [PubMed]

79. Chen, B.J.; Dashnamoorthy, R.; Galera, P.; Makarenko, V.; Chang, H.; Ghosh, S.; Evens, A.M. The immune checkpoint molecules PD-1, PD-L1, TIM-3 and LAG-3 in diffuse large B-cell lymphoma. Oncotarget 2019, 10, 2030-2040. [CrossRef] [PubMed]

80. Sidaway, P. Breast cancer: LAG3 expression indicates favourable outcomes. Nat. Rev. Clin. Oncol. 2017, 14, 712.

81. Burugu, S.; Gao, D.; Leung, S.; Chia, S.; Nielsen, T. LAG-3+ tumor infiltrating lymphocytes in breast cancer: Clinical correlates and association with PD-1/PD-L1+ tumors. Ann. Oncol. 2017, 28, 2977-2984. [CrossRef]

82. Gebauer, F.; Krämer, M.; Bruns, C.; Schlößer, H.A.; Thelen, M.; Lohneis, P.; Schröder, W.; Zander, T.; Alakus, H.; Buettner, R.; et al. Lymphocyte activation gene-3 (LAG3) mRNA and protein expression on tumour infiltrating lymphocytes (TILs) in oesophageal adenocarcinoma. J. Cancer Res. Clin. Oncol. 2020, 146, 2319-2327. [CrossRef] [PubMed]

83. Ohmura, H.; Yamaguchi, K.; Hanamura, F.; Ito, M.; Makiyama, A.; Uchino, K.; Shimokawa, H.; Tamura, S.; Esaki, T.; Mitsugi, K.; et al. OX40 and LAG3 are associated with better prognosis in advanced gastric cancer patients treated with anti-programmed death-1 antibody. Br. J. Cancer 2020, 122, 1507-1517. [CrossRef] [PubMed] 
84. Saleh, R.R.; Peinado, P.; Fuentes-Antrás, J.; Pérez-Segura, P.; Pandiella, A.; Amir, E.; Ocaña, A. Prognostic Value of LymphocyteActivation Gene 3 (LAG3) in Cancer: A Meta-Analysis. Front. Oncol. 2019, 9, 1040. [CrossRef]

85. Li, N.; Jilisihan, B.; Wang, W.; Tang, Y.; Keyoumu, S. Soluble LAG3 acts as a potential prognostic marker of gastric cancer and its positive correlation with CD8+T cell frequency and secretion of IL-12 and INF- $\gamma$ in peripheral blood. Cancer Biomark. 2018, 23, 341-351. [CrossRef]

86. Yu, H.; Yang, J.; Jiao, S.; Li, Y.; Zhang, W.; Wang, J. Cytotoxic T lymphocyte antigen 4 expression in human breast cancer: Implications for prognosis. Cancer Immunol. Immunother. 2015, 64, 853-860. [CrossRef]

87. Xing, X.; Guo, J.; Ding, G.; Li, B.; Dong, B.; Feng, Q.; Li, S.; Zhang, J.; Ying, X.; Cheng, X.; et al. Analysis of PD1, PDL1, PDL2 expression and T cells infiltration in 1014 gastric cancer patients. OncoImmunology 2018, 7, e1356144. [CrossRef]

88. Kong, P.; Wang, J.; Song, Z.; Liu, S.; He, W.; Jiang, C.; Xie, Q.; Yang, L.; Xia, X.; Xia, L. Circulating Lymphocytes, PD-L1 Expression on Tumor-infiltrating Lymphocytes, and Survival of Colorectal Cancer Patients with Different Mismatch Repair Gene Status. J. Cancer 2019, 10, 1745-1754. [CrossRef] [PubMed]

89. Lecocq, Q.; De Vlaeminck, Y.; Hanssens, H.; D’Huyvetter, M.; Raes, G.; Goyvaerts, C.; Keyaerts, M.; Devoogdt, N.; Breckpot, K. Theranostics in immuno-oncologyusing nanobody derivatives. Theranostics 2019, 9, 7772-7791. [CrossRef]

90. Bensch, F.; Van Der Veen, E.L.; Lub-de Hooge, M.N.; Jorritsma-Smit, A.; Boellaard, R.; Kok, I.C.; Oosting, S.F.; Schröder, C.P.; Hiltermann, T.J.N.; Van Der Wekken, A.J.; et al. 89Zr-atezolizumab imaging as a non-invasive approach to assess clinical response to PD-L1 blockade in cancer. Nat. Med. 2018, 24, 1852-1858. [CrossRef]

91. Niemeijer, A.N.; Leung, D.; Huisman, M.C.; Bahce, I.; Hoekstra, O.S.; Van Dongen, G.A.M.S.; Boellaard, R.; Du, S.; Hayes, W.; Ferguson-Smith, A.C.; et al. Whole body PD-1 and PD-L1 positron emission tomography in patients with non-small-cell lung cancer. Nat. Commun. 2018, 9, 4664. [CrossRef]

92. Breitz, H.B.; Tyler, A.; Bjorn, M.J.; Lesley, T.; Weiden, P.L. Clinical experience with Tc-99m nofetumomab merpentan (Verluma) radioimmunoscintigraphy. Clin. Nucl. Med. 1997, 22, 615-620. [CrossRef] [PubMed]

93. Kelly, M.P.; Tavare, R.; Giurleo, J.T.; Makonnen, S.; Hickey, C.; Danton, M.A.; Arnold, T.C.; Ma, D.; Dai, J.; Pei, J.; et al. Abstract 3033: Immuno-PET detection of LAG-3 expressing intratumoral lymphocytes using the zirconium-89 radiolabeled fully human anti-LAG-3 antibody REGN3767. Tumor Biol. 2018, 78, 3033. [CrossRef]

94. Ducharme, M.; Lapi, S.E. Peptide Based Imaging Agents for HER2 Imaging in Oncology. Mol. Imaging 2020, 19. [CrossRef] [PubMed]

95. Lecocq, Q.; Zeven, K.; De Vlaeminck, Y.; Martens, S.; Massa, S.; Goyvaerts, C.; Raes, G.; Keyaerts, M.; Breckpot, K.; Devoogdt, N. Noninvasive Imaging of the Immune Checkpoint LAG-3 Using Nanobodies, from Development to Pre-Clinical Use. Biomolecules 2019, 9, 548. [CrossRef] [PubMed]

96. Chakravarty, R.; Goel, S.; Cai, W. Nanobody: The "magic bullet" for molecular imaging? Theranostics 2014, 4, 386-398. [CrossRef] [PubMed]

97. Debie, P.; Vanhoeij, M.; Poortmans, N.; Puttemans, J.; Gillis, K.; Devoogdt, N.; Lahoutte, T.; Hernot, S. Improved Debulking of Peritoneal Tumor Implants by Near-Infrared Fluorescent Nanobody Image Guidance in an Experimental Mouse Model. Mol. Imaging Biol. 2017, 20, 361-367. [CrossRef] [PubMed]

98. Van Der Linden, R.; Frenken, L.G.J.; De Geus, B.; Harmsen, M.; Ruuls, R.; Stok, W.; De Ron, L.; Wilson, S.; Davis, P.B.; Verrips, C. Comparison of physical chemical properties of llama VHH antibody fragments and mouse monoclonal antibodies. Biochim. Biophys. Acta 1999, 1431, 37-46. [CrossRef]

99. Muruganandam, A.; Tanha, J.; Narang, S.; Stanimirovic, D. Selection of phage-displayed llama single-domain antibodies that transmigrate across human blood-brain barrier endothelium. FASEB J. 2001, 16, 1-22. [CrossRef]

100. Abulrob, A.; Sprong, H.; Henegouwen, P.V.B.E.; Stanimirovic, D. The blood-brain barrier transmigrating single domain antibody: Mechanisms of transport and antigenic epitopes in human brain endothelial cells. J. Neurochem. 2005, 95, 1201-1214. [CrossRef]

101. Li, T.; Bourgeois, J.; Celli, S.; Glacial, F.; Le Sourd, A.; Mecheri, S.; Weksler, B.; Romero, I.; Couraud, P.; Rougeon, F.; et al. Cell-penetrating anti-GFAP VHH and corresponding fluorescent fusion protein VHH-GFP spontaneously cross the blood-brain barrier and specifically recognize astrocytes: Application to brain imaging. FASEB J. 2012, 26, 3969-3979. [CrossRef]

102. Keyaerts, M.; Xavier, C.; Heemskerk, J.; Devoogdt, N.; Everaert, H.; Ackaert, C.; Vanhoeij, M.; Duhoux, F.P.; Gevaert, T.; Simon, P.; et al. Phase I Study of 68Ga-HER2-Nanobody for PET/CT Assessment of HER2 Expression in Breast Carcinoma. J. Nucl. Med. 2015, 57, 27-33. [CrossRef] [PubMed]

103. Grosso, J.F.; Kelleher, C.C.; Harris, T.J.; Maris, C.H.; Hipkiss, E.L.; De Marzo, A.; Anders, R.; Netto, G.; Getnet, D.; Bruno, T.C.; et al. LAG-3 regulates CD8+ T cell accumulation and effector function in murine self- and tumor-tolerance systems. J. Clin. Investig. 2007, 117, 3383-3392. [CrossRef] [PubMed]

104. Goding, S.R.; Wilson, K.A.; Xie, Y.; Harris, K.M.; Baxi, A.; Akpinarli, A.; Fulton, A.; Tamada, K.; Strome, S.E.; Antony, P.A. Restoring Immune Function of Tumor-Specific CD4+ T Cells during Recurrence of Melanoma. J. Immunol. 2013, 190, 4899-4909. [CrossRef] [PubMed]

105. Huang, R.-Y.; Eppolito, C.; Lele, S.; Shrikant, P.; Matsuzaki, J.; Odunsi, K. LAG3 and PD1 co-inhibitory molecules collaborate to limit CD8+ T cell signaling and dampen antitumor immunity in a murine ovarian cancer model. Oncotarget 2015, 6, 27359-27377. [CrossRef] [PubMed]

106. Huang, R.-Y.; Francois, A.; McGray, A.R.; Miliotto, A.; Odunsi, K. Compensatory upregulation of PD-1, LAG-3, and CTLA-4 limits the efficacy of single-agent checkpoint blockade in metastatic ovarian cancer. OncoImmunology 2017, 6, e1249561. [CrossRef] 
107. Harris-Bookman, S.; Mathios, D.; Martin, A.M.; Xia, Y.; Kim, E.; Xu, H.; Belcaid, Z.; Polanczyk, M.; Barberi, T.; Theodros, D.; et al. Expression of LAG-3 and efficacy of combination treatment with anti-LAG-3 and anti-PD-1 monoclonal antibodies in glioblastoma. Int. J. Cancer 2018, 143, 3201-3208. [CrossRef]

108. Burova, E.; Hermann, A.; Dai, J.; Ullman, E.; Halasz, G.; Potocky, T.; Pei, J.; Hong, S.; Liu, M.; Allbritton, O.; et al. Faculty Opinions recommendation of Preclinical Development of the Anti-LAG-3 Antibody REGN3767: Characterization and Activity in Combination with the Anti-PD-1 Antibody Cemiplimab in Human PD-1xLAG-3-Knockin Mice. Mol. Cancer Ther. 2020, 18, 2051-2062. [CrossRef]

109. Wierz, M.; Pierson, S.; Guyonnet, L.; Viry, E.; Lequeux, A.; Oudin, A.; Niclou, S.P.; Ollert, M.; Berchem, G.; Janji, B.; et al. Dual PD1/LAG3 immune checkpoint blockade limits tumor development in a murine model of chronic lymphocytic leukemia. Blood 2018, 131, 1617-1621. [CrossRef]

110. Kraman, M.; Faroudi, M.; Allen, N.L.; Kmiecik, K.; Gliddon, D.; Seal, C.; Koers, A.; Wydro, M.M.; Batey, S.; Winnewisser, J.; et al. FS118, a Bispecific Antibody Targeting LAG-3 and PD-L1, Enhances T-Cell Activation Resulting in Potent Antitumor Activity. Clin. Cancer Res. 2020, 26, 3333-3344. [CrossRef]

111. LaMotte-Mohs, R.; Shah, K.; Smith, D.; Gorlatov, S.; Ciccarone, V.; Tamura, J.; Li, H.; Rillema, J.; Licea, M.; He, L.; et al. Abstract 3217: MGD013, a bispecific PD-1 x LAG-3 Dual-Affinity Re-Targeting (DART®) protein with T-cell immunomodulatory activity for cancer treatment. Immunology 2016, 76, 3217. [CrossRef]

112. Ascierto, P.A.; Bono, P.; Bhatia, S.; Melero, I.; Nyakas, M.S.; Svane, I.M.; Larkin, J.; Gomez-Roca, C.; Schadendorf, D.; Dummer, R.; et al. LBA18-Efficacy of BMS-986016, a monoclonal antibody that targets lymphocyte activation gene-3 (LAG-3), in combination with nivolumab in pts with melanoma who progressed during prior anti-PD-1/PD-L1 therapy (mel prior IO) in all-comer and biomarker-enric. Ann. Oncol. 2017, 28, v611-v612. Available online: http://www.sciencedirect.com/science/article/pii/S09237 53420391110 (accessed on 6 November 2020). [CrossRef]

113. Hong, D.S.; Schoffski, P.; Calvo, A.; Sarantopoulos, J.; De Olza, M.O.; Carvajal, R.D.; Prawira, A.; Kyi, C.; Esaki, T.; Akerley, W.L.; et al. Phase I/II study of LAG525 \pm spartalizumab (PDR001) in patients (pts) with advanced malignancies. J. Clin. Oncol. 2018, 36, 3012. [CrossRef]

114. Pieris Pharmaceuticals PRS 332 Adinsight. Available online: https://adisinsight.springer.com/drugs/800055543 (accessed on 6 November 2020).

115. Hedvat, M.; Moore, G.; Bernett, M.; Bonzon, C.; Avery, K.; Rashid, R.; Nisthal, A.; Muchhal, U.; Desjarlais, J. p664 33rd Annual Meeting \& Pre-Conference Programs of the Society for Immunotherapy of Cancer (SITC 2018). J. Immunother. Cancer $2018,6,115$.

116. Brignone, C.; Gutierrez, M.; Mefti, F.; Brain, E.; Jarcau, R.; Cvitkovic, F.; Bousetta, N.; Medioni, J.; Gligorov, J.; Grygar, C.; et al. First-line chemoimmunotherapy in metastatic breast carcinoma: Combination of paclitaxel and IMP321 (LAG-3Ig) enhances immune responses and antitumor activity. J. Transl. Med. 2010, 8, 71. [CrossRef]

117. Avice, M.N.; Sarfati, M.; Triebel, F.; Delespesse, G.; Demeure, C.E. Lymphocyte activation gene-3, a MHC class II ligand expressed on activated T cells, stimulates TNF-alpha and IL-12 production by monocytes and dendritic cells. J. Immunol. 1999, 162, 2748-2753.

118. Buisson, S.; Triebel, F. MHC class II engagement by its ligand LAG-3 (CD223) leads to a distinct pattern of chemokine and chemokine receptor expression by human dendritic cells. Vaccine 2003, 21, 862-868. [CrossRef]

119. Legat, A.; Hajjami, H.M.-E.; Baumgaertner, P.; Cagnon, L.; Maillard, S.A.; Geldhof, C.; Iancu, E.M.; Lebon, L.; Guillaume, P.; Dojcinovic, D.; et al. Vaccination with LAG-3Ig (IMP321) and Peptides Induces Specific CD4 and CD8 T-Cell Responses in Metastatic Melanoma Patients—Report of a Phase I/IIa Clinical Trial. Clin. Cancer Res. 2016, 22, 1330-1340. [CrossRef] [PubMed]

120. Wang-Gillam, A.; Plambeck-Suess, S.; Goedegebuure, P.; Simon, P.O.; Mitchem, J.B.; Hornick, J.R.; Sorscher, S.; Picus, J.; Suresh, R.; Lockhart, A.C.; et al. A phase I study of IMP321 and gemcitabine as the front-line therapy in patients with advanced pancreatic adenocarcinoma. Investig. New Drugs 2013, 31, 707-713. [CrossRef] [PubMed]

121. Romano, E.; Michielin, O.; Voelter, V.; Laurent, J.; Bichat, H.; Stravodimou, A.; Romero, P.; Speiser, D.E.; Triebel, F.; Leyvraz, S.; et al. MART-1 peptide vaccination plus IMP321 (LAG-3Ig fusion protein) in patients receiving autologous PBMCs after lymphodepletion: Results of a Phase I trial. J. Transl. Med. 2014, 12, 97. [CrossRef] 